This item was submitted to Loughborough's Research Repository by the author.

Items in Figshare are protected by copyright, with all rights reserved, unless otherwise indicated.

\title{
Samuel Field - founding father of the IMF
}

PLEASE CITE THE PUBLISHED VERSION

PUBLISHER

(C) Maney Publishing

VERSION

VoR (Version of Record)

LICENCE

CC BY-NC-ND 4.0

REPOSITORY RECORD

Gabe, D.R.. 2009. "Samuel Field - Founding Father of the IMF". figshare. https://hdl.handle.net/2134/4509. 
This item was submitted to Loughborough's Institutional Repository (https://dspace.lboro.ac.uk/) by the author and is made available under the following Creative Commons Licence conditions.

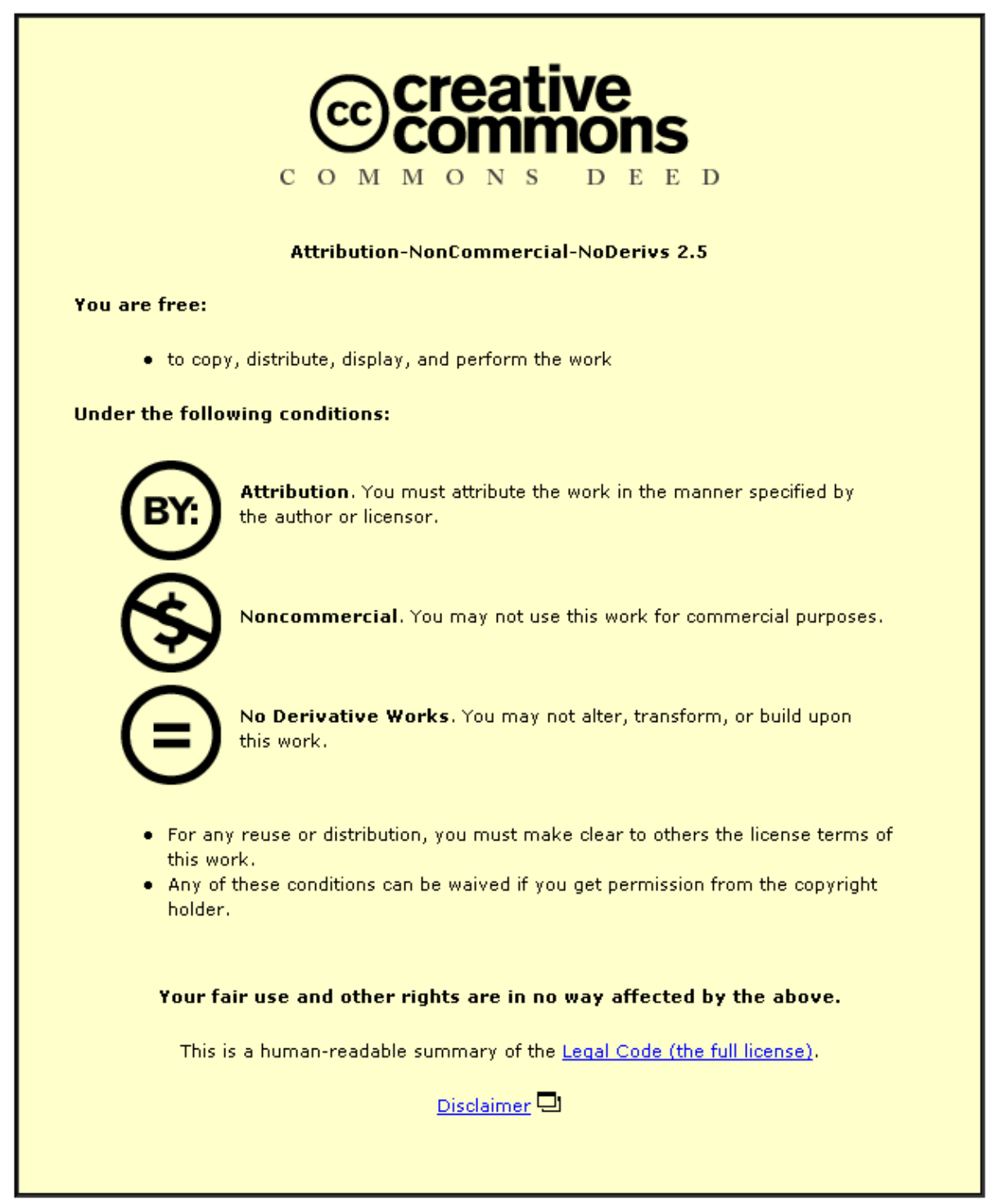

For the full text of this licence, please go to: http://creativecommons.org/licenses/by-nc-nd/2.5/ 


\title{
Samuel Field - founding father of the IMF
}

\author{
D. R. Gabe*
}

\begin{abstract}
If anyone can claim to have founded the Institute it would be Samuel Field, although in practice he was the driving force for a small group to meet and take the decision in 1925. At that time metal finishing had a strong hold in East London and the Northampton Polytechnic was not only a meeting place but could offer basic training courses in a subject that was strongly craft based with not too much science. Samuel Field was the man who identified a need and set out to satisfy that need.
\end{abstract}

Samuel Field was born in the Birmingham district of Winson Green on 8 April 1875. At the age of 13 he won a scholarship to study at the Midlands Institute, from which he went at the age of 21 to the Royal College of Science (now part of Imperial College London) to study chemistry. He graduated with the ARCS and $\mathrm{BSc}$ (Lond) degrees and took a number of teaching posts including at Croydon Technical College, an area in which he lived for much of his life. He was head of the Department of Technical Chemistry at Roehampton Polytechnic but it was at Northampton Polytechnic in Clerkenwell that he exercised his greatest influence. He had been a member of the Faraday Society since 1911 and had noted the growing commerce in electroplating based on sketchy science and set about training himself through the City and Guilds education programmes, becoming an honours medallist in electrometallurgy. Thus equipped he began evening courses in the early 1920s finding a group of enthusiastic supporters who sought a means of sponsoring discussion meetings which the Faraday Society felt unable to satisfy. However, they were happy to support the creation of an associated society to meet this need. Samuel Field was the focal point and he convened a meeting on 11 November 1925 at which a

*IPTME, Loughborough University, Loughborough LE11 3TU, UK decision was taken to found the Electroplaters and Depositors Technical Society (EDTS); a list was made of the founder supporters and subscriptions taken. The list contained leading names such as Spiers, MacNaughton, James, Harris and Field; and others were added within months including the young Simon Wernick. The formal founding was therefore on 11 November from which meeting Field became the first President, William Harris the first secretary, William James the first treasurer. Donald MacNaughton and Frederick Spiers were the sponsoring members from the Faraday Society.

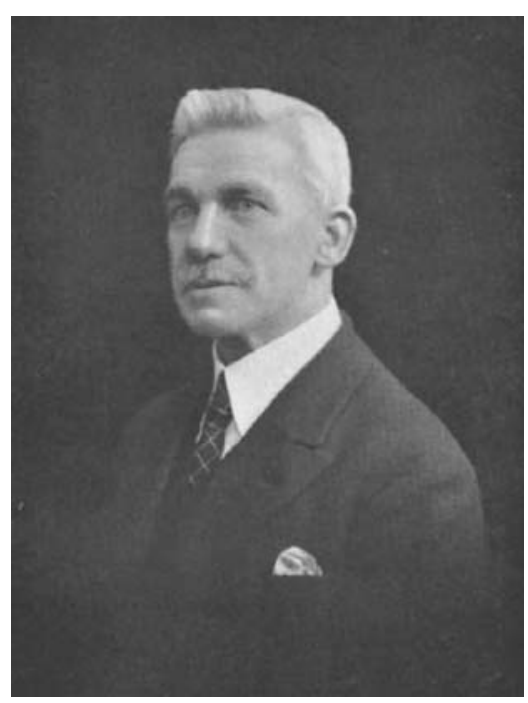

Portrait of Samuel Field at the time of his Presidency (1926-29)

Amongst the decisions taken were the need to promote and record technical discussions, hence the Transactions (of the EDTS) was founded with volume 1 published in 1925-26, courses were commenced with formal structure at the Polytechnic, and a textbook was sponsored (co-authored with Dudley Weill), appearing in 1930 as 'Electroplating: a survey of modern practice'.1

This textbook has become a lasting memorial. Although not the first to deal with the technology (his own book of $1911^{2}$ and that of Blum and Hogaboom ${ }^{3}$ in 1924 have prior claims) it was a landmark in attempting to develop a technical science for electrodeposition. By 1951, it had expanded to a sixth edition and Dudley Weill continued as co-author as Field had retired in the 1930s.

While his earliest textbook was published in 1911, a later one in 1944 also took the main title of 'The principles of electrodeposition', ${ }^{4}$ but gave the rather different emphasis of electrochemistry; neither, however, captured the student need in quite the same manner as the joint one with Weill. Nevertheless these books were important both for teaching and helping the managers of plating shops to relate science to practice; this approach was apparent in Field's willingness to address the regular EDTS discussion meetings with reviews of current practice in the light of scientific principles.

Basic research was not Field's forte and he obviously was happy to leave it to industrial laboratories, notably that at Woolwich Arsenal led by MacNaughton and Hothersall. The books are notable for practical developments, one of which he encouraged related to the measurement of throwing power. An American formula was in use in 1920 giving a range of values from 0 to $80 \%$; he strongly encouraged use of a revised formula giving symmetrical values from -100 to $+100 \%$ and this was adopted as a British Standard in the 1930s on the basis of his test results. The books also did much to standardise the chemical methods of solution analysis.

Field retired in 1940 but during the war he taught science at Poole Grammar School as a staff replacement. After the war he returned to Croydon where he died on 6 November 1965 at the age of 90, having been active to the end. His affinity to general science and the need to popularise it was also seen in his work as science correspondent of the Daily Telegraph during the 1920s. After 1945 he retired quietly and took little further part in the Society and the later Institute. 
The EDTS and Institute of Metal Finishing honoured him in several ways. He was first President, serving for four years from 1925 to 1929, and became the first honorary member in 1951. The Gold Medal was instituted in 1947 and he was selected to be the first recipient. The Institute must forever be in his debt for his leadership in creating the Society that we now know as the Institute of Metal Finishing

\section{Tributes}

Anon: Trans. IMF, 1966, 44, (2), B20.

S.Wernick: Trans. IMF, 1966, 44, 97, 99-101.

\section{References}

1. S. Field and A.D. Weill: 'Electroplating: a survey of modern practice', 1st edn; 1930, London, Pitman (6th edn, 1951) (546 pp.).
2. S. Field: 'The principles of electrodeposition: a laboratory guide to electroplating'; 1911, London, Longman's Green (383 pp.).

3. W. Blum and G. B. Hogaboom: 'Principles of electroplating and electroforming', 1st edn; 1924, New York, NY, McGraw-Hill.

4. S. Field: 'The principles of electrodeposition: the electrochemistry of electroplating'; 1944, London, Pitman (314 pp.).

\section{Current Literature}

A regular round-up of the contents of the recent journals of the IMF's sister societies and surface engineering magazines.

\section{Galvanotechnik}

200899 (9) September

Highly corrosion-resistant nickel/gold surfaces

Kurtz, O., Lagorce-Broc, F., Danker, M. et al.

Characterising electrodeposited coatings - Part II: Ductility and microhardness

Allmendinger, Th.

Simulation as a tool for thickness control of chromium plating

Lander, H., Deconinck, J., Dorochenko,

A. and Nelissen, $G$.

Technology and equipment for ultrasonic cleaning of electronic components

Lanin, V. and Tomalj, V.

Comments on zinc-nickel deposition Gysen, B.

Thermally sprayed permanent magnetic coatings

Dzur, B., Linke, P., Zimmer, C. and

Thomas, $G$.

The global energy requirement Mais, E.-R.

Recycling process water with vacuum evaporators

Isenburg, Th.

\section{Electroplating \& Finishing (China)}

200827 (2) Serial No. 140

Effect of hydrogen evolution on the growth of nickel dendrite by electrodeposition WANG Gui-feng, HUANG Yin-hui, TIAN Zong-jun, et al.

Application of electrochemical impedance spectroscopy on the research of electrodeposition - Part II YUAN Guo-wei
Research status and development of $\mathrm{Ni}-\mathrm{Cr}$ alloy electrodeposition YANG Yu-fang and LI Qiang-guo

Wear resistant $\mathrm{Fe}-\mathrm{Al}_{2} \mathrm{O}_{3}$ plating deposit QIN Yue-lin

Effect of current density on performances of deposit in low-temperature plating process LIU Yi, YANG Sen, YIN Jin-jie et al.

Recovery of zinc and manganese from waste dry batteries and electrodeposition with recovered solution MA Ya-qin, LONG Jin-ming and DU Ai-hua

Study on the technical preparation of $\mathrm{Pd}$ membrane by electroless plating on porous a- $\mathrm{Al}_{2} \mathrm{O}_{3}$ ceramic

ZHANG Bao-shu and HOU Kai-hu

Hot galvanising technology and its pollution control

NIE Yu-hua and WANG Wen-ying

Application status of methylsulphonate in tin-based alloy plating WANG Ya-xiong and HUANG Ying-hong

Study on preparation and wear resistance of nano- $\mathrm{Al}_{2} \mathrm{O}_{3}$ ceramic coatings on magnesium alloy MA Zhuang, LU Wen-tao, SHI Hai-fang et al.

Experience of successful practicing green electroplating and material recycling - part two

WONG Luther

Replying to RoHS and developing recycling economy - discussion of two pop topics on electroplating cleaner production

XING Wen-chang

Nano- $\mathrm{TiO}_{2}$ coating prepared on 304 stainless steel by liquid phase deposition ZENG Zhen-ou, XIAO Zheng-wei and ZHAO Guo-peng
Modification and abrasion resistance of acrylic based finishing varnish with nano- $\mathrm{SiO}_{2}$

YAN Yong, DAI Ji-zhu and ZHANG

Xiao-hua

Coating techniques of bus body YAN Bo-chang

Coating technology for nuclear power plant equipment

ZHANG Yao and QIAO Liang

Effect of inorganic nano-particles on UV-curing powder coatings ZHOU Shi-biao, ZHANG Wei-qing, LI Lin et al.

200827 (3) Serial No. 141

Applications of electrochemical impedance spectroscopy to the research of electrodeposition - Part III YUAN Guo-wei

Potential activation phenomenon and non-cyanide direct copper plating FENG Shao-bin and HU Fang-hong

Practice of non-cyanide alkaline copper plating process

XU Jin-Lai, DENG Zheng-ping, ZHAO

Guo-peng, et al.

Cyanide-free electroplating process of copper-tin alloy with high tin content LIU Jian-ping

Novel process for plating antique tin LU Jing-chun

Analysis of common problems in alkaline tin plating on copper foil CHEN Wei-jian

Review of alternatives to nickel plating saving techniques

YUAN Shi-pu

Study on lead- and cadmium-free composite additive for electroless nickel plating LIU Hai-ping, LI Ning, BI Si-fu, et al. 
Trivalent chrome passivation process used in the hot-dip galvanising of insulator hard-ware fittings.

MIAO Li-xian, LIU Yan-jun, MIAO Ying, et al.

Effect of ac pore-enlarging on electrolytic colouring of anodised aluminium film

WANG Hua, TAO Wei, ZHANG Dou, et al.

Study on environmental protection type surface treatment technology of electrolytic copper foil

YANG Xiang-kui, HU Xu-ri and ZHENG Xiao-wei

Analysis of the components of acid chemical colouring solutions for stainless steel

GONG Shan-hua, XUE Yong-qiang and LUAN Chun-hui

Study on liquid polybutadiene cathodic electrophoretic coatings

QIN Shu-chao, WANG Jin-wei, HE Ye-dong et al.

Application of airless spraying machine to steel structure coating - part one LI Min-feng

Anti-corrosion coating quality control of the concrete structure in tidal areas LI Yun-de, ZHANG Guang-zhi and YANG Zhen-bo

Oxidation resistant coating technology applied to steel billet in high temperature dynamic process WEI Lian-qi, YE Shu-feng, SUN Wei-hua et al.

Establishment of computer system for colour matching latexes

CHEN Ming-yi, CHEN Bing-yao and CHEN Bing-qiang

200827 (4) Serial No. 142

Study on decorative tin-zinc-nickel ternary alloy electroplating process as an alternative to nickel plating ZOU Wei-hong, DENG Zheng-ping, HU Yao-hong, et al.

Study of trivalent chromium iridescent passivation technology producing high corrosion resistance for electroplated zinc coatings

BI Si-fu, TU Zhen-mi, LI Ning, et al.

Research status of environmentfriendly passivation processes for zinc plating coatings

LIAO Xiu-juan and WEI Ming-kun

Design and manufacture of micro-barrel applied to electroplating

LUO Fu-lin

Improvement of red copper electroforming process for the production of lightning rod WANG Qing-hao
Present status of the research on electroforming of nanocrystalline materials

DU Ai-hua, LONG Jin-ming and PEI He-zhong

Influence of phosphorus mass fraction on structure and properties of electroless nickel coating on magnesium alloy JIANG Jian-peng, YU Hong-ying, SUN Dong-bai et al.

Process of electroless nickel plating on iron-based powder metallurgy articles YU Li-yan, XIE Hun, LU Yan-wei, et al.

Preliminary study on electroless nickel plating for surface modification of carbon fibre

ZHANG Ji-qiao, YANG Yu-guo, ZHU Hong et al.

Assessment of adhesion strength of mechanical galvanising coating by pull-off test method

GUO Li-jie, HE Ming-yi, WANG

Sheng-min, et al.

Performance analysis and quality assessment of anodic coatings on aluminium alloy architectural shapes ZHU Zu-fang

Analysis on pollution links in PCB process and cleaner production - part two

\section{ZHANG Zong-yi}

Preparation of silica sol fireproofing coating for aluminium alloy surface CUI Xue-jun, LI Guo-jun, and REN Rui-ming

Research on waterborne epoxy-siliceous polyurethane corrosion protection coatings

SUN Dao-xing and DING Xiao-bin

Study on environment-friendly coil primer

LI Rui, FENG Quan-fen, HAO Long, et al.

Preparation of low toxicity and volatility paint stripper

SUN Jie, ZHAO Wu-qiang, MENG

Jin-hong, et al.

\section{Corrosion Management}

2008 No.84 July/August

Protective developments - Sol-gel

systems show promise in antifouling and anticorrosive systems

Akid, R. and Wang, $H$

2008 No. 85 September/October

Corrosion in electronics

Jellesen, M.S., Westermann, P.,

Rathinavelu, U., et al.

\section{Metal Finishing}

2008106 (4) April

Non-chrome containing conversion coatings for zinc and zinc alloys Bibber, J. W.

2008106 (10) October

$\mathrm{pH}$ measurement in aqueous and non-aqueous solutions

Quitmeyer, J

The black barrier: characteristics of high-performance black passivates for zinc substrates

Dingworth, B. and Bishop, C. V.

Process map for plasma sprayed aluminium oxide-carbon nanotube nanocomposite coatings Balini, K. and Agarval, A.

\section{Plating \& Surface Finishing} (incl. JASF)

200895 (8) August

NASF REACH education effort - NASF supplier guidance

C. Richter and J Hannapel

JASF 20083 (3) (available on WWW.nasf.org)

Electrodeposition of Sn-0.7wt\% Cu eutectic alloys from chloride-citrate solutions

C. Han, Qi Liu and D.G. Ivey

Corrosion resistance of ELV-compliant mid-and-low/mid-phosphorus electroless nickel

N. Mycyus

Design and validation of conformal anodes for a thermal barrier coating on a triple vane

G. Nelissen, B. Van den Bossche, A. Rose and J. Foster

Magnesium repair by cold spray Champagne, V., Helfritch, D. and Leyman P. F.

Operational experience using organically-stabilised electroless nickel

Beckett, D.

High-speed electroless nickel-PTFE plating

Feldstein, M., Lancsek, T. and

Thotathil, J.

200895 (9) September

EPA plating and polishing area source final Rule

Richter, C. and Hannapel, J.

Unlimited oil?

Dini, J.W. 